\title{
The Critical Period of Corn Crops (Zea Mays L.) Due to Weed Competition on Various Soil Processing Systems
}

\author{
Warlinson Girsang ${ }^{\text {a }}$ Eko Wibowo ${ }^{b}$ \\ ${ }^{\mathrm{a}}$ lecturer Fakultas Pertanian Universitas Simalungun Pematangsiantar Indonesia ${ }^{\mathrm{b}}$ Graduate of \\ agrotechnology study program Fakultas Pertanian Universitas Simalungun Pematangsiantar Indonesia \\ Email:purbationer@yahoo.co.id
}

\begin{abstract}
:
The research was conducted in October 2016 - February 2017 at Huta Sait Buttu Saribu, Pematang Sidamanik sub-district of Simalungun district, altitude of place $+1100 \mathrm{~m}$ asl. The purpose of this research is to understand the critical period of corn crops (Zea mays L.) due to weed competition in various soil systems. The research implementation methodology used a split plot design (SPD) with randomized block experimental design. The treatment consists of two factors, namely the land treatment system (T) as the main plot and the weed investment period (W) as the subplot. The soil processing system consists of 3 types, i.e. without soil treatment (T0), minimum tillage (T1), and intensive tillage (T2). While the investment period of weeds is designed in 10 treatments, namely $\mathrm{W} 1=$ free weed for $0-15 \mathrm{DAP}, \mathrm{W} 2=$ free weed for 0-30 DAP, W3 = free weed 0-45 DAP, W4 = free weed 0-60 DAP, W5 = free weed until harvest, $\mathrm{W} 6=$ weeds from planting to harvest, $\mathrm{W} 7=$ weeds for 0-60 DAP, W8 = weeds for 0-45 DAP, W9 = weeds for 0-30 DAP, and W10 = weeds for 0-15 DAP. Each treatment was repeated 3 times. To determine the effect of the two treatments, observation towards the dominance of weeds (summed dominance ratio), the period of silk delay (day), height of plant $(\mathrm{cm})$, root dry weight $(\mathrm{g})$, leaf area $(\mathrm{cm} 2)$, and dry seed production per plot $(\mathrm{kg})$ is done. From the result of research data analysis, noted that soil processing system is influencing the root dry weight, plant height, total leaf area and seed production per plot, but the period of silk delay is not influenced by difference of soil processing system. The difference in weed investment time affects the period of silk delay, plant height, root dry weight, leaf area and seed weight per plot. The interaction of both treatments affects plant height, root dry weight, leaf area, and seed weight per plot. But period of silk delay is not influenced by the interaction of the two treatments. From the research results, concluded that the critical period of corn crop growth due to weed competition occurs when in the period of 0-60 DAP weeds are allowed to compete with corn crops.
\end{abstract}

Keywords: corn, weed, critical period, soil processing

\section{Introduction}

The demand for corn (Zea mays L.) in Indonesia is currently quite large, i.e. more than 10 million tons of dry corn grains per year [25]. From the market side, corn marketing potential continues to increase. Beside as food ingredients for human consumption, corn is also needed in large quantities for a mixture of fodder. As a cereal crop, corn can grow almost in all regions notes that the average production of Sumatera Utara corn is 50.13 quintals per hectare. Compared with the potential of superior seed production which can reach 10 ton of dry corn grains / hectare, the production of corn in Sumatra Utara and also nationally is still considered low.

The low production of corn in Indonesia, according to [25], among others, is due to the not yet widespread use of superior varieties and cultivation methods that do not meet the recommendations. Busra, Bahri, and Zaini (1997) stated that soil cultivation and crop management which are not optimal yet, plus with pests and weed diseases, affecting the corn productivity per unit area.

The productivity of corn plants is strongly influenced by the environmental conditions. A corn crops land which left to be overgrown with weeds will cause losses. Because, between weeds and corn crops will compete for resources that are 
equally needed. Weeds are undesired plants because they interfere with cultivated plants, due to competition for nutrient, water, light, and growing space. For that, it is necessary to do manipulation and control efforts, so that the negative effects of weeds towards corn crops can be minimized.

However, the actual existence of weeds throughout the life cycle of corn crops does not always negatively affect those cultivated plants. There is a certain time span, the existence of weeds is not too detrimental to the growth of corn. Conversely, there is an interval of time at a particular growth stage where the plant is very sensitive to weed competition.

The presence or appearance of weeds in that time period with a certain density will lead to a significant decrease in yield. The period of time when plants are susceptible to competition with weeds is known as the critical period of the plant.

To control the existence of weeds appropriately, one step that must be done is to predict and determine the critical period of the plant appropriately. If the critical period is predict correctly, so weed control will be effective and plant growth will produce maximum production.

Soil processing and crop management also affect plant growth and production. The primary goal of tillage is to prepare a harmonious and good place for plant growth, improve soil physical properties and suppress weed growth (Sadjad, 1976; Sinukaban, 1990). Soil treatment systems can result in controlled weed populations or vice versa (Aldrich, 1984), and may cause changes in the dominance of weed species (Utomo, Bangun, and Rahman, 1995).

The soil processing system determines the physical properties of the soil [22]. and affects microclimates, plant growth, and weed composition[1]. Soil treatment also affects the availability and loss of groundwater [6]. Proper soil cultivation can preserve soil and water[12], but in certain circumstances it can reduce water available especially on dry land. In intensive processing, water loss through evaporation becomes enlarged [13]. The stability of low and eroding soil aggregates [29], as well as causing compaction under layers [2]. To minimize the adverse effects, soil processing techniques need to be studied. Some authors $[5 ; 9 ; 11 ; 16 ;]$. suggest the need to restrict the processing of sufficient soil alone, including minimum soil treatment, without soil treatment, or conservation land preparation.

\section{Research Methodology}

The in-field experiment was conducted at Huta Sait Buttu Saribu, Pematang Sidamanik subdistrict of Simalungun district, altitude of place + $1100 \mathrm{~m}$ above sea level. Historical land research, previously a dry field moors with a former cultivation of corn crops. The research began in October 2016 and ended in February 2017.

The materials used in the research are corn seed Pioneer 22 varieties. Chemical fertilizers in the form of urea are used as a source of nitrogen, SP36 as a source of phosphorus and $\mathrm{KCl}$ as a source of potassium elements. To control the pests that attack the plant in the field, insecticide Curater 3 $\mathrm{G}$ and Matador $25 \mathrm{EC}$ is used.

Tools for cultivating the soil and planting are hoes, rakes, machete and wood stick. Tools for measurement of observation variables are: scales, meters, and stationeries. Other tools used include: plastic bucket, measuring cylinder, water can, water hose, knapsack sprayer, scissors, label board, signpost name and others.

The research implementation methodology used a split plot design (SPD) with randomized block experimental design. The treatment consists of two factors, namely the land treatment system (T) as the main plot and the weed investment period (W) as the subplot. The soil processing system consists of 3 types, i.e. without soil treatment $\left(\mathrm{T}_{0}\right)$, minimum tillage $\left(T_{1}\right)$, and intensive tillage $\left(T_{2}\right)$. While the investment period of weeds is designed in 10 treatments, namely $\mathrm{W}_{1}=$ free weed for $0-15$ DAP, $W_{2}=$ free weed for 0-30 DAP, $W_{3}=$ free weed 0-45 DAP, $\mathrm{W}_{4}=$ free weed 0-60 DAP, $\mathrm{W}_{5}=$ free weed until harvest, $\mathrm{W}_{6}=$ weeds from planting to harvest, $\mathrm{W}_{7}=$ weeds for $0-60 \mathrm{DAP}, \mathrm{W}_{8}=$ weeds for 0-45 DAP, $\mathrm{W}_{9}=$ weeds for 0-30 DAP, and $\mathrm{W}_{10}=$ weeds for 0-15 DAP. Each treatment was repeated 3 times. Implementation of the research includes preparation and processing of land, planting, fertilizing, maintenance and implementation of the treatment of weed and harvesting investment.

To determine the effect of both treatments, the observations were made on: (a) the dominance ratio of weeds (summed dominance ratio) and (b) parameters of growth and production of corn, including: period of silk delay, plant height, root dry weight, leaf area, and dry seed production per plot. The analysis of research data was done by Anova, using mathematical model $\mathrm{Y}_{\mathrm{ijk}}=\mu+\Gamma_{\mathrm{i}}+$ $\alpha_{\mathrm{j}}+\sigma_{\mathrm{ij}}+\beta_{\mathrm{k}}+(\alpha \beta)_{\mathrm{jk}}+\sum_{\mathrm{ijk}}[8]$. 


\section{Results and Discussion}

\section{A. The Dominance of Weed (Summed Dominance Ratio)}

The shifting dominance of weeds occurs due to soil tillage and herbicide application. The change of dominance of the weeds can be seen in Table 1 below.

Table 1. The value of Summed Dominance Ratio (\%) Vegetation of Weeds Before and After the Treatment of Soil Processing System at 12 MST

\begin{tabular}{|c|c|c|c|c|}
\hline \multirow[t]{2}{*}{ Weed Species } & \multicolumn{4}{|c|}{$\begin{array}{c}\text { Summed Dominance } \\
\text { Ratio }(\%)\end{array}$} \\
\hline & $\begin{array}{c}\text { Star } \\
\mathrm{t}\end{array}$ & T0 & $\mathrm{T} 1$ & $\mathrm{~T} 2$ \\
\hline \multicolumn{5}{|l|}{ Berdaun lebar: } \\
\hline $\begin{array}{l}\text { Euphorbia hirta L } \\
\text { (Patikan Kebo) }\end{array}$ & 3.10 & $\begin{array}{c}2.3 \\
7\end{array}$ & $\begin{array}{c}7.0 \\
0\end{array}$ & $\begin{array}{l}13 . \\
37\end{array}$ \\
\hline $\begin{array}{l}\text { Ageratum conyzoides } \\
\text { (Babadotan) }\end{array}$ & 3.11 & $\begin{array}{c}3.0 \\
7\end{array}$ & $\begin{array}{l}10 . \\
63\end{array}$ & $\begin{array}{l}22 . \\
92\end{array}$ \\
\hline Bidens pilosa (Ketul) & 4.86 & $\begin{array}{c}1.7 \\
5\end{array}$ & $\begin{array}{c}7.0 \\
2\end{array}$ & $\begin{array}{c}8.4 \\
4\end{array}$ \\
\hline $\begin{array}{l}\text { Borreira lauvicaulis } \\
\text { (Kenikir) }\end{array}$ & $\begin{array}{c}13.4 \\
0\end{array}$ & $\begin{array}{c}6.6 \\
0\end{array}$ & $\begin{array}{l}11 . \\
35\end{array}$ & $\begin{array}{l}19 . \\
78\end{array}$ \\
\hline $\begin{array}{l}\text { Erechtites } \\
\text { valerianifolia } \\
\text { (Sintrong) }\end{array}$ & 3.83 & $\begin{array}{c}3.4 \\
5\end{array}$ & $\begin{array}{c}3.7 \\
4\end{array}$ & $\begin{array}{c}6.3 \\
1\end{array}$ \\
\hline $\begin{array}{l}\text { Elephantopus scaber } \\
\text { (Tapak Liman) }\end{array}$ & 1.92 & $\begin{array}{c}2.4 \\
7 \\
\end{array}$ & $\begin{array}{c}4.1 \\
2 \\
\end{array}$ & $\begin{array}{c}3.1 \\
7\end{array}$ \\
\hline $\begin{array}{l}\text { Polygonum barbatum } \\
\text { (Mengkrengan) }\end{array}$ & 3.59 & $\begin{array}{c}1.4 \\
1\end{array}$ & - & $\begin{array}{c}4.3 \\
8\end{array}$ \\
\hline Sub Total & $\begin{array}{c}33.7 \\
9\end{array}$ & $\begin{array}{l}21 . \\
12\end{array}$ & $\begin{array}{l}43 . \\
86\end{array}$ & $\begin{array}{l}78 . \\
37\end{array}$ \\
\hline \multicolumn{5}{|l|}{ Berdaun sempit: } \\
\hline $\begin{array}{l}\text { Eleusine indica } \\
\text { (Rumput Belulang) }\end{array}$ & 8.22 & $\begin{array}{l}13 . \\
48\end{array}$ & - & - \\
\hline $\begin{array}{l}\text { Setaria plicata } \\
\text { (Jambean) }\end{array}$ & $\begin{array}{c}10.8 \\
5\end{array}$ & $\begin{array}{l}10 . \\
45\end{array}$ & $\begin{array}{l}12 . \\
07\end{array}$ & $\begin{array}{l}11 . \\
28\end{array}$ \\
\hline $\begin{array}{l}\text { Brachiaria distachya } \\
\text { (Kabak-kabakan) }\end{array}$ & 1.83 & $\begin{array}{c}9.0 \\
9 \\
\end{array}$ & - & - \\
\hline $\begin{array}{l}\text { Paspalum conjugatum } \\
\text { (Rumput Paitan) }\end{array}$ & $\begin{array}{c}13.6 \\
1\end{array}$ & $\begin{array}{l}21 . \\
04\end{array}$ & $\begin{array}{l}20 . \\
42\end{array}$ & $\begin{array}{c}6.3 \\
7\end{array}$ \\
\hline $\begin{array}{l}\text { Imperata cylindrical } \\
\text { (Alang-alang) }\end{array}$ & 6.67 & - & - & - \\
\hline $\begin{array}{l}\text { Paspalum disticum } \\
\text { (Rumput Pahit) }\end{array}$ & 6.51 & $\begin{array}{l}12 . \\
20\end{array}$ & $\begin{array}{c}9.9 \\
7 \\
\end{array}$ & $\begin{array}{c}3.9 \\
8\end{array}$ \\
\hline $\begin{array}{l}\text { Panicum } \\
\text { sarmentosum } \\
\text { (Benggala) }\end{array}$ & 2.75 & - & - & - \\
\hline Sul & 504 & 6 & 2 & \\
\hline
\end{tabular}

\begin{tabular}{|c|c|c|c|c|}
\hline & 5 & 24 & 46 & 63 \\
\hline \multicolumn{5}{|l|}{ Teki-tekian } \\
\hline $\begin{array}{l}\text { Cyperus rotundus } \\
\text { (Rumput Teki) }\end{array}$ & 6.92 & $\begin{array}{c}4.2 \\
1\end{array}$ & $\begin{array}{c}5.3 \\
8\end{array}$ & - \\
\hline $\begin{array}{l}\text { Cyperus brevifolius } \\
\text { (Jukut Pendul) }\end{array}$ & 8.85 & $\begin{array}{c}8.4 \\
2\end{array}$ & $\begin{array}{c}8.2 \\
9\end{array}$ & - \\
\hline Sub Total & $\begin{array}{c}15.7 \\
6\end{array}$ & $\begin{array}{l}12 . \\
63\end{array}$ & $\begin{array}{l}13 . \\
68\end{array}$ & - \\
\hline Total & 100 & $\begin{array}{c}10 \\
0\end{array}$ & $\begin{array}{c}10 \\
0\end{array}$ & $\begin{array}{c}10 \\
0\end{array}$ \\
\hline \multicolumn{5}{|c|}{$\begin{array}{c}\text { Description: } \text { Start }=\text { before treatment, } \mathrm{T} 0= \\
\text { without tillage, } \mathrm{T} 1=\text { minimum } \\
\text { tillage, } \mathrm{T} 2=\text { intensive soil }\end{array}$} \\
\hline
\end{tabular}

Preliminary identification compared with identification at 12 MST (Table 1) showed a change of weeds dominance in the research field. Prior to land clearing, weed vegetation was dominated by a narrow-leaved group with an SDR of $50.45 \%$, then a $33.79 \%$ wide-leaved group, followed by a $15.76 \%$ sedges group.

After land clearing, there is a shift of growing weeds dominance. The $\mathrm{T} 2$ treatment plot (intensive soil process) was dominated by wideleaved weeds with $78.37 \%$ SDR, and followed by narrow-leaved weeds with $21.63 \%$ SDR. By cultivating the land perfectly, there is a change in the soil physical nature i.e. created loose soil. This supports the dormant seeds in the soil emerging into the upper layers so that in the T2 plot the is dominated by wide-leaved weeds. Generally wideleaved weed multiplication more effectively breed with seeds. In addition, due to the condition of loose soil will facilitate the seeds carried by the wind or bird droppings falling on the T2 plot grows as new weeds. This result is in line with the opinion of [28]. which stated due to soil processing treatment or due to the application of herbicides may occur the shifting of weed species on a field. By the presence of more intensive soil treatment, it shows a shift of weed species, becoming dominated by wide-leaved weeds.

The T1 treatment plot was also dominated by wide-leaved weeds with a $43.86 \%$ SDR that was comparable to narrow-leaved weeds with $42.46 \%$ SDR and the smallest group of sedges with $12.63 \%$ SDR. The T0 treatment plot was dominated by narrow-leaved weeds with $50.45 \%$ SDR, followed by wide-leaved weeds with $33.79 \%$ SDR, and the smallest group of sedges with $15.76 \%$ SDR. In the soil without soil treatment (T0), the presence of weeds at initial 
observations and 12 MST observations remained dominated by narrow-leaved weeds.

\subsection{Corn Growth and Yields}

To determine the critical period of corn crop (Zea mays L.) due to weed competition in various soil processing systems, observation and data collection of growth and yield of corn by measuring parameters: the period of silk delay (day), plant height $(\mathrm{cm})$, root dry weight (gr), leaf area $(\mathrm{cm} 2)$ and seed production per plot $(\mathrm{kg})$. Anova result of the research data showed that the soil processing system $(\mathrm{T})$, the weed investment period $(\mathrm{W})$ and interaction ( $\mathrm{TxW}$ ) affected plant height, root dry weight, leaf area and seed production per plot. Specifically to the period of silk delay parameter, the result of Anova indicates that the treatment of soil processing system $(\mathrm{T})$ does not affect the the period of corn crop silk delay. However, the period of weed investment (W) significantly affects the period of silk delay. Treatment interaction $(\mathrm{TxW})$ does not affect the period of silk delay.

Table 2 shows the results of differences in period of silk delay (day), plant height $(\mathrm{cm})$, root dry weight (gr), leaf area $(\mathrm{cm} 2)$ and seed production per plot $(\mathrm{kg})$ due to competition with weeds on various soil systems.

Table 2. The Averages Difference Test Result of The Period of Silk Delay, Plant Height, Root Dry Weight, Leaf Area and Production Seeds Per Plot Due To Competition With Weeds On Various Soil Processing Systems

\begin{tabular}{|l|l|l|l|l|l|}
\hline $\begin{array}{l}\text { tre } \\
\text { at } \\
\text { me } \\
\mathrm{nt}\end{array}$ & $\begin{array}{l}\text { Lengt } \\
\text { h of } \\
\text { time } \\
\text { Silk } \\
\text { Delay } \\
\text { (day) }\end{array}$ & $\begin{array}{l}\text { Plant } \\
\text { height } \\
(\mathrm{cm})\end{array}$ & $\begin{array}{l}\text { Root } \\
\text { dry } \\
\text { weigh } \\
\mathrm{t}(\mathrm{g})\end{array}$ & $\begin{array}{l}\text { Leaf } \\
\text { Area } \\
\left(\mathrm{cm}^{2}\right)\end{array}$ & $\begin{array}{l}\text { Seed } \\
\text { productio } \\
\mathrm{n} \\
\text { /Plot }(\mathrm{kg})\end{array}$ \\
\hline $\mathrm{T}_{0}$ & 1,77 & $\begin{array}{l}161,7 \\
\mathrm{a}\end{array}$ & $7,9 \mathrm{a}$ & $\begin{array}{l}3598, \\
8 \mathrm{a}\end{array}$ & $1,41 \mathrm{a}$ \\
\hline $\mathrm{T}_{1}$ & 1,75 & $\begin{array}{l}179,7 \\
\mathrm{~b}\end{array}$ & $9,5 \mathrm{~b}$ & $\begin{array}{l}4637, \\
6 \mathrm{~b}\end{array}$ & $2,12 \mathrm{~b}$ \\
\hline $\mathrm{T}_{2}$ & 1,70 & $\begin{array}{l}184,5 \\
\mathrm{~b}\end{array}$ & $10,1 \mathrm{~b}$ & $\begin{array}{l}4964, \\
5 \mathrm{~b}\end{array}$ & $2,17 \mathrm{~b}$ \\
\hline $\mathrm{W}_{1}$ & $\begin{array}{l}1,84 \mathrm{c} \\
\mathrm{d}\end{array}$ & $\begin{array}{l}162,6 \\
\mathrm{~b}\end{array}$ & $4,3 \mathrm{a}$ & $\begin{array}{l}3459, \\
5 \mathrm{~b}\end{array}$ & $1,66 \mathrm{bc}$ \\
\hline $\mathrm{W}_{2}$ & $\begin{array}{l}1,84 \mathrm{c} \\
\mathrm{d}\end{array}$ & $\begin{array}{l}170,2 \\
\mathrm{bc}\end{array}$ & $4,6 \mathrm{a}$ & $\begin{array}{l}3683, \\
6 \mathrm{bc}\end{array}$ & $1,73 \mathrm{bcd}$ \\
\hline $\mathrm{W}_{3}$ & $\begin{array}{l}1,77 \mathrm{~b} \\
\mathrm{~cd}\end{array}$ & $\begin{array}{l}176,2 \\
\mathrm{bc}\end{array}$ & $4,9 \mathrm{ab}$ & $\begin{array}{l}4081, \\
2 \mathrm{c}\end{array}$ & $1,90 \mathrm{bcd}$ \\
\hline $\mathrm{W}_{4}$ & $1,61 \mathrm{a}$ & 191,7 & $7,0 \mathrm{bc}$ & 5515, & $2,18 \mathrm{de}$ \\
\hline
\end{tabular}

\begin{tabular}{|c|c|c|c|c|c|}
\hline & & de & $\mathrm{d}$ & $8 d$ & \\
\hline $\mathrm{W}_{5}$ & $1,58 \mathrm{a}$ & $\begin{array}{l}200,0 \\
\mathrm{e}\end{array}$ & $7,5 d$ & $\begin{array}{l}6180 \\
4 \mathrm{e}\end{array}$ & $2,52 \mathrm{e}$ \\
\hline $\mathrm{W}_{6}$ & $1,93 d$ & $\begin{array}{l}142,8 \\
\mathrm{a}\end{array}$ & $4,2 \mathrm{a}$ & $\begin{array}{l}1449, \\
2 \mathrm{a}\end{array}$ & $0,91 \mathrm{a}$ \\
\hline $\mathrm{W}_{7}$ & $\begin{array}{l}1,84 \mathrm{c} \\
\mathrm{d}\end{array}$ & $\begin{array}{l}163,1 \\
b\end{array}$ & $\begin{array}{l}5,2 a b \\
c\end{array}$ & $\begin{array}{l}3363, \\
3 b\end{array}$ & $1,65 b$ \\
\hline $\mathrm{W}_{8}$ & $\begin{array}{l}1,74 a \\
b c\end{array}$ & $\begin{array}{l}166,6 \\
b\end{array}$ & $\begin{array}{l}6,1 a b \\
c d\end{array}$ & $\begin{array}{l}3593 \\
71 \mathrm{bc}\end{array}$ & $1,84 \mathrm{bcd}$ \\
\hline $\mathrm{W}_{9}$ & $\begin{array}{l}1,68 \mathrm{a} \\
\mathrm{bc}\end{array}$ & $\begin{array}{l}183,2 \\
\mathrm{~cd}\end{array}$ & $\begin{array}{l}6,8 b c \\
d\end{array}$ & $\begin{array}{l}5329 \\
05 \mathrm{~d}\end{array}$ & 2,15 cde \\
\hline \begin{tabular}{l|}
$\mathrm{W}_{1}$ \\
0
\end{tabular} & $1,58 \mathrm{a}$ & $\begin{array}{l}196,6 \\
\text { de }\end{array}$ & $7,2 \mathrm{~cd}$ & $\begin{array}{l}5844, \\
08 \mathrm{de}\end{array}$ & $2,43 \mathrm{e}$ \\
\hline $\begin{array}{l}\mathrm{T}_{0} \\
\mathrm{~W}_{1}\end{array}$ & 1,87 & $\begin{array}{l}157,5 \\
\mathrm{c}\end{array}$ & $6,0 \mathrm{ab}$ & $\begin{array}{l}2983, \\
8 b\end{array}$ & $0,98 b$ \\
\hline $\begin{array}{l}\mathrm{T}_{0} \\
\mathrm{~W}_{2}\end{array}$ & 1,87 & $\begin{array}{l}158,4 \\
\mathrm{~cd}\end{array}$ & $6,3 b c$ & $\begin{array}{l}3081 \\
8 b c\end{array}$ & $1,13 c$ \\
\hline $\begin{array}{l}\mathrm{T}_{0} \\
\mathrm{~W}_{3}\end{array}$ & 1,87 & $\begin{array}{l}162,1 \\
\text { def }\end{array}$ & $6,6 \mathrm{~cd}$ & $\begin{array}{l}3606, \\
2 \text { efg }\end{array}$ & $1,45 \mathrm{e}$ \\
\hline $\begin{array}{l}\mathrm{T}_{0} \\
\mathrm{~W}_{4}\end{array}$ & 1,68 & $\begin{array}{l}169,4 \\
\text { fghi }\end{array}$ & $9,1 \mathrm{~h}$ & $\begin{array}{l}4477 \\
2 \mathrm{kl}\end{array}$ & $1,66 f g$ \\
\hline $\begin{array}{l}\mathrm{T}_{0} \\
\mathrm{~W}_{5}\end{array}$ & 1,58 & $178,4 \mathrm{j}$ & $10,0 \mathrm{i}$ & $\begin{array}{l}4855 \\
\mathrm{~m}\end{array}$ & $1,85 \mathrm{hi}$ \\
\hline $\begin{array}{l}\mathrm{T}_{0} \\
\mathrm{~W}_{6}\end{array}$ & 1,95 & $\begin{array}{l}133,4 \\
\mathrm{a}\end{array}$ & $5,7 \mathrm{a}$ & $\begin{array}{l}1449 \\
2 \mathrm{a}\end{array}$ & $0,77 \mathrm{a}$ \\
\hline $\begin{array}{l}\mathrm{T}_{0} \\
\mathrm{~W}_{7}\end{array}$ & 1,77 & $\begin{array}{l}156,8 \\
\mathrm{c}\end{array}$ & $7,5 \mathrm{e}$ & $\begin{array}{l}3265, \\
2 \mathrm{~d}\end{array}$ & $1,31 \mathrm{~d}$ \\
\hline $\begin{array}{l}\mathrm{T}_{0} \\
\mathrm{~W}_{8}\end{array}$ & 1,77 & $\begin{array}{l}159,5 \\
\mathrm{~cd}\end{array}$ & $8,2 \mathrm{~g}$ & $\begin{array}{l}3597 \\
5 \text { efg }\end{array}$ & $1,53 \mathrm{ef}$ \\
\hline $\begin{array}{l}\mathrm{T}_{0} \\
\mathrm{~W}_{9}\end{array}$ & 1,77 & $\begin{array}{l}166,9 \\
\text { efgh }\end{array}$ & $9,3 \mathrm{~h}$ & $\begin{array}{l}4174 i \\
j k\end{array}$ & $1,66 \mathrm{fg}$ \\
\hline $\begin{array}{l}\mathrm{T}_{0} \\
\mathrm{~W}_{1} \\
0\end{array}$ & 1,58 & $174,9 \mathrm{j}$ & $9,8 \mathrm{i}$ & $\begin{array}{l}4497, \\
81\end{array}$ & $1,73 \mathrm{~g}$ \\
\hline $\begin{array}{l}\mathrm{T}_{1} \\
\mathrm{~W}_{1}\end{array}$ & 1,87 & $\begin{array}{l}161,9 \\
\text { cde }\end{array}$ & $6,9 d$ & $\begin{array}{l}3577, \\
\text { 8ef }\end{array}$ & 1,98ijk \\
\hline $\begin{array}{l}\mathrm{T}_{1} \\
\mathrm{~W}_{2} \\
\end{array}$ & 1,87 & $\begin{array}{l}173,4 \\
\text { hij }\end{array}$ & $7,6 \mathrm{ef}$ & $\begin{array}{l}\text { 3879, } \\
8 \mathrm{ghi}\end{array}$ & $2,02 \mathrm{jkl}$ \\
\hline $\begin{array}{l}\mathrm{T}_{1} \\
\mathrm{~W}_{3} \\
\end{array}$ & 1,77 & $\begin{array}{l}188,0 i \\
j\end{array}$ & $8,2 \mathrm{~g}$ & $\begin{array}{l}4204, \\
6 i j k l \\
\end{array}$ & $2,09 \mathrm{kl}$ \\
\hline $\begin{array}{l}\mathrm{T}_{1} \\
\mathrm{~W}_{4}\end{array}$ & 1,58 & $\begin{array}{l}198,8 \\
\mathrm{~m}\end{array}$ & $12,0 \mathrm{~h}$ & $\begin{array}{l}5537, \\
8 \mathrm{n}\end{array}$ & $2,42 \mathrm{~m}$ \\
\hline $\begin{array}{l}\mathrm{T}_{1} \\
\mathrm{~W}_{5} \\
\end{array}$ & 1,58 & $\begin{array}{l}209,9 \\
\mathrm{~m} \\
\end{array}$ & $\begin{array}{l}12,4 \mathrm{~m} \\
\mathrm{n}\end{array}$ & $\begin{array}{l}6465 \\
2 \mathrm{pq}\end{array}$ & $2,83 n$ \\
\hline $\begin{array}{l}\mathrm{T}_{1} \\
\mathrm{~W}_{6}\end{array}$ & 1,95 & $\begin{array}{l}145,6 \\
b\end{array}$ & $6,8 \mathrm{~d}$ & $\begin{array}{l}3942, \\
\text { 9hij }\end{array}$ & $0,97 b$ \\
\hline $\begin{array}{l}\mathrm{T}_{1} \\
\mathrm{~W}_{7}\end{array}$ & 1,87 & $\begin{array}{l}165,6 \\
\text { defg }\end{array}$ & $8,0 \mathrm{fg}$ & $\begin{array}{l}3248 \\
4 \mathrm{bcd}\end{array}$ & $1,80 \mathrm{gh}$ \\
\hline $\begin{array}{l}\mathrm{T}_{1} \\
\mathrm{~W}_{8} \\
\end{array}$ & 1,77 & $\begin{array}{l}169,0 \\
\text { efghi }\end{array}$ & $10,1 \mathrm{i}$ & $\begin{array}{l}3490, \\
4 d e\end{array}$ & 1,94hij \\
\hline \begin{tabular}{l|}
$\mathrm{T}_{1}$ \\
$\mathrm{~W}_{9}$ \\
\end{tabular} & 1,68 & $\begin{array}{l}188,2 \\
\mathrm{k}\end{array}$ & $11 \mathrm{j}$ & $\begin{array}{l}5746, \\
8 \mathrm{n}\end{array}$ & $2,36 \mathrm{~m}$ \\
\hline
\end{tabular}




\begin{tabular}{|c|c|c|c|c|c|}
\hline $\begin{array}{l}\mathrm{T}_{1} \\
\mathrm{~W}_{1} \\
0\end{array}$ & 1,58 & $\begin{array}{l}207,1 \\
\mathrm{~m}\end{array}$ & $11,9 \mathrm{kl}$ & $\begin{array}{l}6282, \\
6 o p\end{array}$ & $2,76 n$ \\
\hline $\begin{array}{l}\mathrm{T}_{2} \\
\mathrm{~W}_{1}\end{array}$ & 1,77 & $\begin{array}{l}157,5 \\
\text { efghi }\end{array}$ & $7,5 \mathrm{e}$ & $\begin{array}{l}3816, \\
9 f g h\end{array}$ & $2,03 \mathrm{jkl}$ \\
\hline $\begin{array}{l}\mathrm{T}_{2} \\
\mathrm{~W}_{2}\end{array}$ & 1,77 & $178,8 \mathrm{j}$ & $8 \mathrm{fg}$ & $\begin{array}{l}\text { 4089, } \\
\text { 3ghi }\end{array}$ & $2,04 \mathrm{jkl}$ \\
\hline $\begin{array}{l}\mathrm{T}_{2} \\
\mathrm{~W}_{3}\end{array}$ & 1,68 & $\begin{array}{l}188,5 \\
\mathrm{kl}\end{array}$ & $8,9 \mathrm{~h}$ & $\begin{array}{l}4432, \\
9 \mathrm{kl}\end{array}$ & 2,171 \\
\hline $\begin{array}{l}\mathrm{T}_{2} \\
\mathrm{~W}_{4}\end{array}$ & 1,58 & $207 \mathrm{~m}$ & $\begin{array}{l}12,21 \\
\mathrm{mn}\end{array}$ & $\begin{array}{l}6532, \\
5 \mathrm{pq}\end{array}$ & $2,47 \mathrm{~m}$ \\
\hline $\begin{array}{l}\mathrm{T}_{2} \\
\mathrm{~W}_{5}\end{array}$ & 1,58 & $211,7 \mathrm{j}$ & $12,6 n$ & $\begin{array}{l}7221, \\
1 \mathrm{r}\end{array}$ & $2,88 n$ \\
\hline $\begin{array}{l}\mathrm{T}_{2} \\
\mathrm{~W}_{6}\end{array}$ & 1,87 & $\begin{array}{l}149,3 \\
\mathrm{~b}\end{array}$ & $8,0 \mathrm{fg}$ & $\begin{array}{l}3464, \\
7 \mathrm{de}\end{array}$ & $0,99 b c$ \\
\hline $\begin{array}{l}\mathrm{T}_{2} \\
\mathrm{~W}_{7}\end{array}$ & 1,87 & $\begin{array}{l}\text { 167ef } \\
\text { ghi }\end{array}$ & $8,3 \mathrm{~g}$ & $\begin{array}{l}3576, \\
2 \mathrm{efg}\end{array}$ & $1,85 \mathrm{hi}$ \\
\hline $\begin{array}{l}\mathrm{T}_{2} \\
\mathrm{~W}_{8} \\
\end{array}$ & 1,68 & $\begin{array}{l}171,4 \\
\text { ghij }\end{array}$ & $11,1 \mathrm{j}$ & $\begin{array}{l}\text { 3693, } \\
\text { 3efgh }\end{array}$ & $2,04 \mathrm{jkl}$ \\
\hline $\begin{array}{l}\mathrm{T}_{2} \\
\mathrm{~W}_{9} \\
\end{array}$ & 1,58 & 194,61 & $11,7 \mathrm{k}$ & $\begin{array}{l}6066, \\
40 \\
\end{array}$ & $2,43 \mathrm{~m}$ \\
\hline $\begin{array}{l}\mathrm{T}_{2} \\
\mathrm{~W}_{1}\end{array}$ & 1,58 & $\begin{array}{l}207,9 \\
\mathrm{~m}\end{array}$ & $\begin{array}{l}12,3 \mathrm{~m} \\
\mathrm{n}\end{array}$ & $\begin{array}{l}6751, \\
8 \mathrm{q}\end{array}$ & $2,79 n$ \\
\hline
\end{tabular}

Description: The number followed by the same letter notation in the same treatment group in the same column, states not significantly different at the 5\% level based on the Duncan distance test

\section{B. The Period of Silk Delay}

From Table 2 it is known that the period of silk delay is influenced by the weed investment period. The shortest duration of silk delay (1.58 days) is found in the W5 treatment (weed-free until harvest) and the longest is in weeds until harvest treatment (W6) with an average silk delay period of 1.97 days. The period of silk delay on W5 (weed-free until harvest) is not different from W4 treatment (weed 0-60 DAP), W8 (weeds 0-45 DAP), W9 (weeds 0-30 DAP), and W10 (weeds 015 DAP). While the shortest silk delay in the W6 treatment plot (weed to harvest) is not significantly different from W1 (weeds 0-15 DAP), W2 (weed-free 0-30), W3 (weed-free 045), and W7 (weeds 0-60 DAP). In Figure 1 can be seen comparison of silk delay due to weed competition in various soil processing systems.

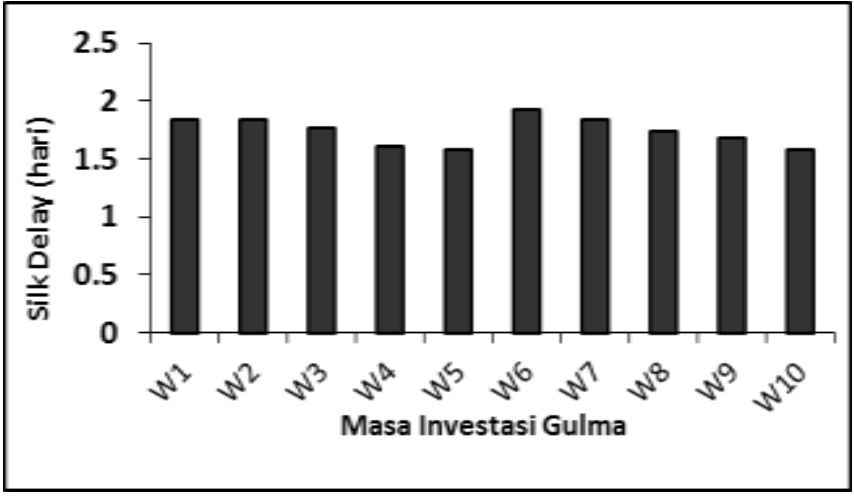

Figure 1. Histogram of Silk Delay Period due to competition with weeds.

The existence of weeds in the treatment plot W7 (weed 0-60 DAP) shows the longest delay, not significantly different from the W6 treatment plot (weeds until harvest) and significantly different from the W10 treatment plot (weed 0-15 DAP). This is sure the critical period of corn crops due to weeds on silk delay parameters occur at about 0-60 DAP and 0-15 DAP or about $12.5-50 \%$ the first day of its harvest age (corn harvest age in the plateau +120 days).

[15] stated, when plants between 33-50 days after plant germination grow rapidly and accumulation of dry matter increases rapidly as well. At present nutrient and water needs are relatively high to support the growth rate of plants. Plant is very sensitive to drought stress and nutrient deficiency. In this phase, drought and nutrient deficiency greatly affect the growth and development of cobs, and will even decrease the number of seeds in a cob due to the shrinking of the cob, which consequently decreases the yield. Drought in this phase will also slow the appearance of female flowers (silking).

In a state of stress (stress) due to lack of water, the appearance of corn-hair may be delayed, while the panicle release is not affected. The interval between the discharge of female flowers and male flowers (anthesis silking interval, ASI) is very important. Small ASI indicates a flowering synchronization, which means that the chances of pure pollination occurrence are enormous. The greater the ASI value the smaller the synchronization of flowering and pollination is hampered resulting in lower yield. Abiotic stress generally affects ASI values, such as drought stress and high temperature. High temperatures and lack of water can cause disturbed pollinating. In such circumstances it 
flatters out faster, but the hair release is slowed (balitsereal.litbang.deptan.go.id).

[7]research result concluded that the period of silk delay correlated significantly with the weight of seed per cobs. The shorter the elapsed time with the appearance of the hair (style), resulting in greater weight per cobs and vice versa. Because in such conditions pollination can take place more perfect and minimize the incidence of cobs do not contain.

Associated with the competition of water taking, under certain circumstances weeds become strong competitors and cause corn crops to lack water. This causes the hair out on the cobs to be longer. Compared to the weed-free treatment plots, the weeded treatment plots over the time period of the analysis of corn crops critical periods to the above weeds were seen to result in longer silk delay. Especially plots contained in the treatment without soil tillage (T0) which is on the dominant analysis of weeds dominated by weeds of the narrow-leaved group. Where the weeds of the narrow-leaved group and the group of sedges have multiple breeding, chronic life cycle, and most streaks of photosynthesis C4 (more efficient metabolism) and relatively more difficult to control. So competition for water and nutrients is stronger and causes longer silk delay.

\section{Plant Height (cm)}

High growth of corn plants are affected by the treatment of soil processing system. The highest plant average $(184.5 \mathrm{~cm})$ was found in the T2 treatment plot (intensive processing soil), followed by T1 (minimum processing soil) and the lowest plant height produced T0 (without tillage) treatment with an average plant height is $161,7 \mathrm{~cm}$.

Treatment of the weed investment period that yields the highest average plant $(200.0 \mathrm{~cm})$ is found in the W5 treatment (weed-free until harvest). While the average height of the lowest plant is in the treatment plot W6 (weeds to harvest).

In the interaction of the soil treatment system and the weed investment period, the highest plant $(211.7 \mathrm{~cm})$ was found in the T2W5 treatment plot (combination of intensive soil and weed-free until harvest) while the lowest plant height was found in the T0W6 treatment plot (no till, weeds until harvest). The plot of treatment T2W5 (intensive processing soil, weed-free until harvest) is not significantly different with T1W4 (minimum processing soil, weed 0-60 DAP), T2W4 (intensive processing soil, free-weed 0-60 DAP) T1W10 (minimum processing soil, weeds 0-15 DAP), T2W10 (intensive processing soil, weeds $0-15$ DAP), and T1W5 (minimum processing soil, weed-free until harvest) .While T0W6 (without tillage, weed until harvest) significantly different from other treatments.

During its lifetime corn crops absorb $\mathrm{N}$ and $\mathrm{P}$ elements. Where these $\mathrm{N}$ and $\mathrm{P}$ elements play an important role in the vegetative growth of corn crops. So that the more intensive processing system facilitate the easier absorption of $\mathrm{N}$ and $\mathrm{P}$ as well as nutrients and other elements by the roots of corn crops. Element $\mathrm{N}$ is required in the formation of amino acid compounds which are protein-forming compounds. So $\mathrm{N}$ is indispensable on the meristem network to grow. In this case to spur the growth of plant height. Increasingly intensive soil treatment can lead to erosion, but with good drainage systems water erosion by water can be overcome.

Hakim et al (1986) stated that soil treatment can improve plant growth through aeration improvement, water movement, and root penetration in soil profile. The soil treatment system also affects the dynamics of weed populations. Referring to the above analysis it is known that in the treatment plot with the increasingly minimal soil processing obtained the higher height of plant. Associated with weed analysis in the previous discussion, the less the soil processing, the higher the number of weeds population of the narrow-leaved group and the class of sedges. [23] stated that grass-weeds and sedges are relatively more competitive compared to wide-leaf weeds.

To determine the critical period of corn competition with weeds, it is important to observe the analysis in table 2 above, especially on intensive weed period treatment. Analyzing the presence of the weeds, the plot of treatment W7 (weed 0-60 DAP) and W8 (weeds 0-45 DAP) showed the lowest plant height in addition to the W6 treatment plot (weeds until harvest), but the plots $\mathrm{W} 7$ and $\mathrm{W} 8$ were significantly different from the W9 treatment plot ( weeds 0-30 DAP). This means the critical period of maize crops with weeds on the plant's high parameters occurs at about 0-45 DAP and 0-30 DAP.

The difference in plant height due to weed competition in various soil systems can be seen in the form of histogram in figure 2 . 


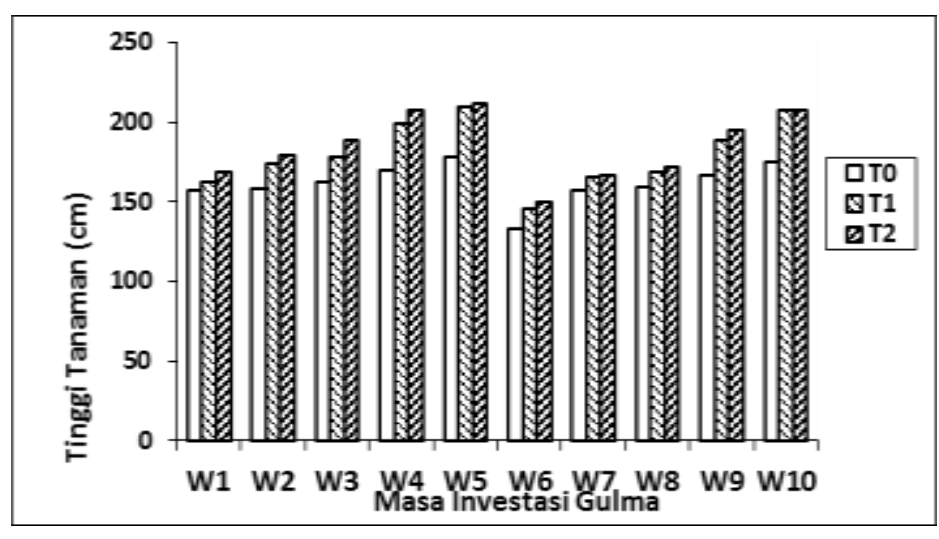

Figure 2. Histogram of corn plants height due to competition with weeds on various land processing systems

\section{Root Dry Weight (g)}

Root dried weights are also affected by the soil treatment system (table 2). In the treatment of the soil treatment system, the highest mean of root dry weight $(10.1 \mathrm{~g})$ was found in the $\mathrm{T} 2$ treatment plot (intensive processing soil), followed by $\mathrm{T} 1$ treatment (minimum processing soil), and the lowest was in T0 treatment (without tillage ).

In the treatment of weed investment period, the highest average of root dry weight was found on the W5 treatment plot (weed-free to harvest) weighing $7.5 \mathrm{~g}$, while the lowest mean dry root weight was found in the treatment plots W6 (weeds to harvest) $4.2 \mathrm{~g}$.

The interaction of soil treatment system and the weed investment period resulting in the highest average of dry root weight (12.6 g) was found in the T2W5 treatment plot (intensive soil, weed-free until harvest) and the lowest dry root weight was found in the treatment plot T0W6 (without tillage, weed until harvest).

Root dry weight in the treatment plot T2W5 (intensive processing soil, weed-free until harvest) was not significantly different from the T1W5 treatment plot (minimum processing soil, weed-free until harvest), the T2W10 treatment plot (intensive soil, weed 0-15 DAP) with the T2W4 treatment plot (intensive soil, free-weed 060 DAP). While the lowest root dry weight found in the T0W6 treatment plot (without tillage, weed until harvest) was not significantly different from the T0W1 treatment plot (no tillage, free-weed 015 DAP).

To determine the critical period of corn competition with weeds, it is necessary to further analyze the average difference test on weed investment period treatment. The difference test of dry root weights from weed competition can be seen in table 6 below.

By analyzing the existence of weeds, the plot of treatment W7 (weed 0-60 DAP), W8 (weed 0-45 DAP), W9 (weed 0-30 DAP), and W10 (weed 0-15 DAP) show the average of root dry weight is similarly low based on the DMRT test in addition to the W6 treatment plot (weed to harvest), and significantly different from W5 (weed-free until harvest). This means the critical period of maize crops with weeds on root dry weight parameters occurs in about 0-60 DAP.

[1] stated, as one aspect of technical culture, soil processing aims to create a good root area, immerse the rest of the plant, and control the weeds. The more intensive soil cultivation, relatively lowered the weight of the soil contents than the minimum soil and no treatment. [25]. Smith et al. (1995) reported, nitrogen fertilization with different doses causes differences in the development (plasticity) of the root system of corn crops.

If soil processing system is associated with weed development, more intensively treated plots show more dominated by wide-leaved weeds. This means that the level of competition of corn with weeds is relatively minimal in the perfect soil processing system when compared with competition between corn crops with grass-weeds and sedges, competition to get nutrients, water, $\mathrm{CO} 2$, and more.

The histogram of root dry weight comparison due to weed competition on various soil processing systems can be seen in Figure 3. From this histogram image can be seen that the higher root weights on the more intensive soil treatment and on the treatment more free of weeds.

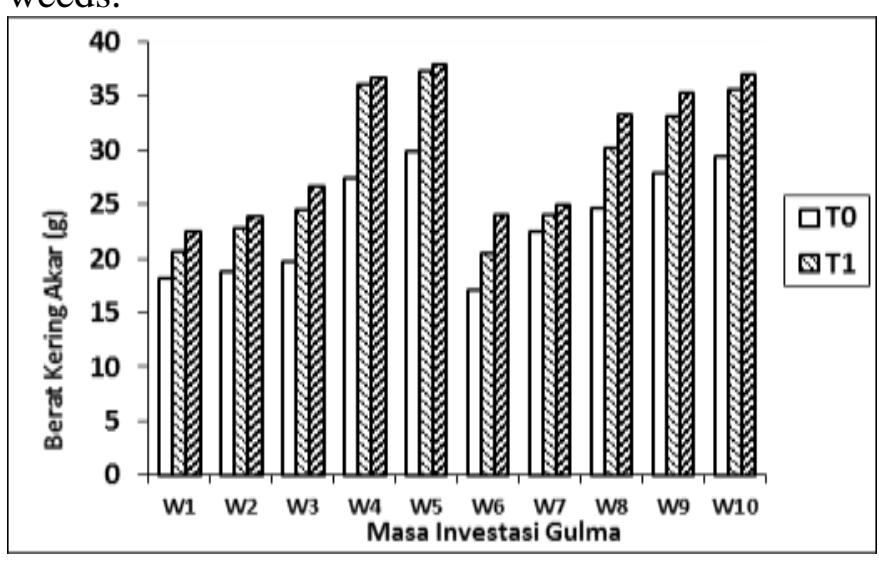

Figure 3. Histograms of root dry weight (g) due to weed competition on various soil systems

\subsection{Leaf area $\left(\mathrm{cm}^{2}\right)$}


The results of Anova in Table 2 indicate that the soil treatment system (T) and the weed investment period (W) and interaction (TxW) affect the area of the corn crops. In the treatment of soil processing systems, the highest average of leaf area $(4964.5 \mathrm{~cm} 2)$ is found in the $\mathrm{T} 2$ treatment plot (intensive processing soil), followed by the T1 (minimum tillage) plot and the lowest T0 (without tillage) with an average area of $3598.8 \mathrm{~cm} 2$.

The treatment of the weed investment period resulting in the highest average leaf area $(6180.4 \mathrm{~cm} 2)$ was found in the W5 treatment plot (weed-free until harvest). While the lowest average leaf area is found in the treatment plot W6 (weeds to harvest) with an area of $1449.2 \mathrm{~cm} 2$.

The interaction of soil processing system and the weed investment period resulting in the highest average leaf area $(7221.1 \mathrm{~cm} 2)$ was found in the T2W5 treatment plot (intensive soil, weedfree to harvest) and the lowest average leaf area was found in the T0W6 treatment plot ( without tillage, weed until harvest) with an area of 1449.2 $\mathrm{cm} 2$. The leaf area in the T2W5 treatment plot (intensive processing soil, weed-free to harvest) was significantly different from that of the other treatments and T0W6 (without tillage, weeds to harvest) was significantly different from the other treatments.

By analyzing the presence of weeds, the plot of treatment W7 (weed 0-60 DAP) and the W8 treatment plot (weed 0-45 DAP) showed the same average low leaf area based on the DMRT Test in addition to the W6 treatment plot (weed to harvest), and significantly different with W9 (weeds 0-30 DAP) as the closest comparator treatment. This means that the critical period of corn with weeds on leaf area parameters occurs at about 0-60 DAP and 0-30 DAP.

Comparison of leaf area on each treatment due to weed competition on various soil systems can be seen in figure 4 .

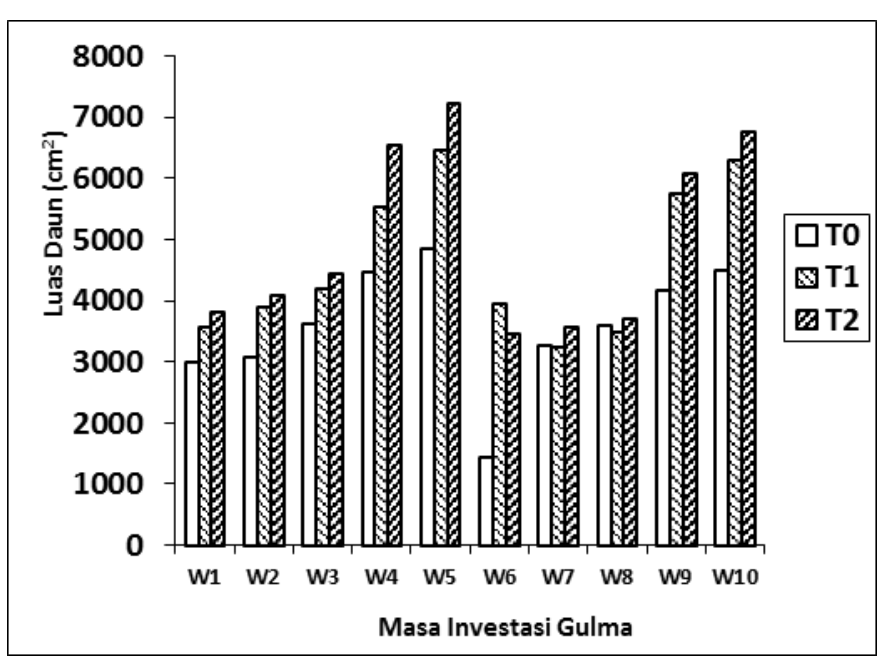

Figure 4. Leaf Area Histogram (cm2) Due to Weed Competition on Various Soil Systems

\subsection{Production of Dry Seeds per Plot (kg)}

The treatment of soil processing system that produced the highest dry seed production per plot $(2.17 \mathrm{~kg})$ was found in the T2 treatment plot (intensive processing soil), followed by the T1 (minimum tillage) treatment plot and the lowest T0 (without tillage) average dry seed production per plot is $1.41 \mathrm{~kg}$.

The highest average yield of weed seeds per hectare was found on the W5 treatment plot (weed-free to harvest) weighing $2.5 \mathrm{~kg}$, while the lowest dry seed production per plot was found in the W6 treatment plot (weed to harvest) with area $0.91 \mathrm{~kg}$.

The interaction of soil processing system and the time of weed investment resulting in the highest dry seed production per plot $(2.88 \mathrm{~kg})$ was found in the T2W5 treatment plot (intensive processing soil, weed-free to harvest) and the lowest average dry seed yield per plot in the treatment of T0W6 (without tillage, weeds to harvest) weighing $0.6 \mathrm{~kg}$

The production of dry seed per plot in the T2W5 treatment plot (intensive soil, weed-free until harvest) was not significantly different from the T1W5 treatment plot (minimum tiilage, weedfree until harvest), T1W10 (minimum tillage, weeds 0-15 DAP) and T2W10 (intensive soil, weeds 0-15 DAP). While the plot of treatment T0W6 (without tillage, weed until harvest) is different with other treatment plots.

To get the highest production need to do intensive weed-free soil until harvest, that is 7,688 ton / Ha. It should be noted, however, that the highest yield is not significantly different from the minimum weed-free soil treatment until the 
harvest, that is 7,546 tons / ha and the intensive processing soil treatment plot weeds 0-15 DAP with yield of 7.431 ton / Ha or with the minimum soil treatment plot weeds 0-15 DAP with a yield of 7.360 tons / ha

To obtain good production, we need to avoid the existence of weeds in the critical period of corn competition with weeds. McWilliam et al (1999) stated that when corn is between 33-50 days after germination, plants grow rapidly and accumulation of dry matter increases rapidly as well. Nutrient and water requirements are relatively high to support the growth rate of plants. Plant is very sensitive to drought stress and nutrient deficiency. In this phase, drought and nutrient deficiency greatly affect the growth and development of cobs and will even decrease the number of seeds in a cob due to the shrinking of the cob, which consequently decreases the yield. Drought in this phase will also slow the appearance of female flowers (silking).

Indirectly, the critical period of corn crops due to weeds on the silk delay parameter is the critical period for seed dry weight parameter to be produced by cobs. From this relationship, we need to avoid the existence of weeds at the time of male flower discharge. In this research, the fastest rate of discharge was 59 days. Weeds indirectly affect the process or fertilization, seed filling and seed quality.

By looking at the weeds after the male flower (tassel) is formed, the plot of treatment W6 (weeds to harvest) shows the lowest result. W4 treatment plot (weed 0-60 DAP), which means at 61 DAP, weeding was stopped and afterwards left to weeds. This means that W4 is outside the critical period of corn due to its competition on silk delay observation but the existence of the weeds is in the formation period of male flowers and the discharge of female flowers (silk), but actually weeds have not shown the competition with corn plant because it is still in the process of germination and precisely corn crops will win the competition. Proven W4 (free weed 0-60 DAP) shows not significantly different result from W5 (weed-free to harvest), but not W1 (weed-free 015 DAP), W2 (weed 0-45 DAP), and W3 (free weed 0-30 DAP).

Soil processing gives effect on the bulk density of soil. [25]. Situmeang (2011) stated that bulk density is a clue to soil density. The denser a land the higher the bulk density, which means the more difficult to continue the water or penetrate the roots of the plant. If it is linked to the weed system with weed development, the more intensively processed plots tend to be dominated by wide-leaved weeds. This means that the level of competition of corn with weeds is relatively minimal in the perfect soil processing system when compared with competition between corn crops with plots T0 which is more dominated by grass weeds and group of sedges.

According to Moody (1977, in Rachman and Efris, 1994), weeds are able to absorb N, P, K, $\mathrm{Ca}$, and $\mathrm{Mg}$ respectively $2.0 ; 1.6 ; 3.6 ; 7.6$; and 3.3 times more than corn. This leads to competitive competition in the ground. Rachman and Efris (1994) reported that the yield of corn was negatively correlated with weeds. The higher the weed dry weight, the more decreased the production obtained.

Weeds of the narrow-leaved group and class of sedges have multiple breeding, chronic life cycle, and most stratified photosynthesis C4 (more efficient metabolism) and relatively more difficult to control and more competitive. Wideleaf weeds, simpler propagation tools, annual life cycles, and relatively unbearable shade.

Differences of weed vegetation in the treatment plots and the results of plant height analysis that differ significantly between soil tillers confirmed the statement of Sukman and Yakup (1995) above. The weight of dry seed per plot in the non treatment soil plot (T0) dominated by grass-weed and sedges is significantly different from the minimum treatment soil (T1) and by intensive processing (T2) which is dominated by wide-leaved weeds.

Comparison of dry seed production per plot $(\mathrm{kg})$ due to weed competition on various soil systems can be seen in the form of histogram in figure 5 .

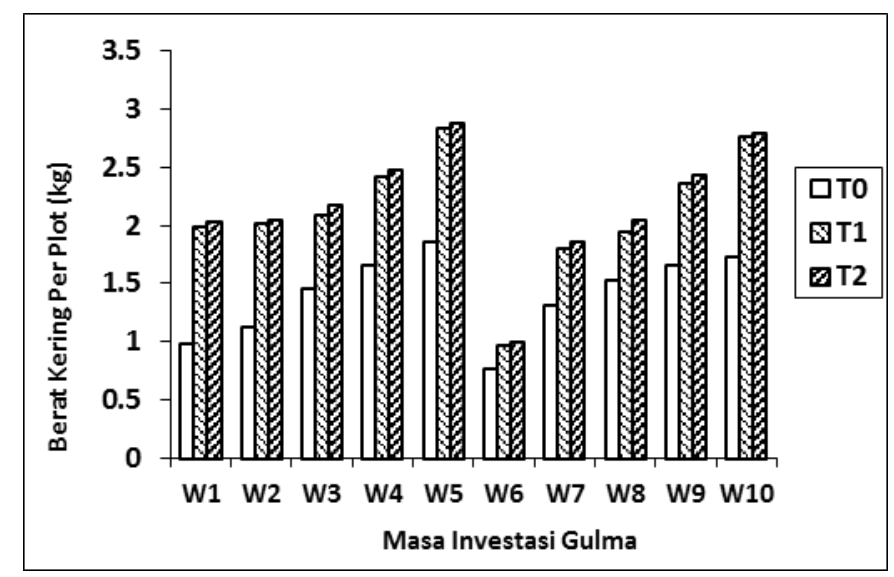


Figure 5. Histogram of dry seed weight per plot $(\mathrm{kg})$ due to weed competition on various soil systems

\section{Conclusions and Recommendations}

\subsection{Conclusion}

1. Differences of soil processing systems affect root dry weight, seed weight per plot, plant height and total area of corn plant leaves. But in particular the period of silk delay, the difference of soil processing system does not show any real effect.

2 . The best soil processing system to minimize weed competition and to support the growth and production of corn crops is by perfect soil processing system.

3. Differences in the investment period of weeds competing with corn plants affect the period of silk delay, root dry weight, seed weight per plot, plant height and total leaf area.

4. The interaction of soil processing and weed investment period combination affected the root dry weight, the weight of corn seeds per plot, the plant height and the total leaf area. But period of silk delay parameter is not affected by the combination of soil processing with the weed investment period.

5. To obtain the maximum growth and production of corn kernels, we need to avoid the existence of weeds in the critical period of corn, i.e. 0-60 days after planting.

\subsection{Suggestion}

It is recommended to conduct the same research on different places, soil types, varieties and planting seasons.

\section{References}

[1] Aldrich, R.J. 1984. Weed Crop Ecology Priciples in Weed Management. Wadsworth, Icn., Belmont, California, USA.

[2] Amemiya, M. 1977. Conservation Tillage in the Western Corn Belt. J. Soil Water Conserv. 32 : 29-36. Arsyad, S. 1989. Konservasi Tanah dan Air. Lembaga Sumberdaya Informasi- IPB. Hal : 38-74. Baldwin, F. L. and P. W. Santlemann. 1980. Weed Science in Integrated Pest Management. Bio Science 30 (10) balitsereal.litbang.deptan.go.id diakses 7 Juni 2013.

[3] Bangun, P. 1985. Pengendalian Gulma pada Tanaman Jagung, Dalam Subandi, M. Syam, S.O. Manurung dan Yuswandi (Eds.). Hasil Penelitian Jagung, Sorgum, Terigu. Risalah Rapat Teknis Puslitbangtan, 28-29 Maret 1985. Puslitbangtan

[4] Bangun, P., dan A. S. Karama. 1998. Tanaman Pangan Dengan Metode Tanpa Olah Tanah dan Diolah Minimum. J. Penel. Pengb. Pertanian, Bogor.

[5] Blenvis, R.L. 1984. Soil Adaptability for NoTillage In : R.L.Philips and B.L Philips (eds) No-Tillage Agriculture Principles and Practice. Van Nostrand Reinhold Company Inc.

[6] Busyra, L. Bahri dan Z. Zaini. 1991. Pengolahan Tanah dan Pengendalian Gulma untuk Tanaman Jagung Setelah Padi di Lahan Kering dan Sawah Tadah Hujan. Pros. Penel. Komoditas dan Studi Kasus. AARP-Dirjen Dikti Depdikbud, Jakarta.

[7] Girsang, W.1999. Studi Dinamika Populasi Gulma Serta Pertumbuhan dan Hasil Jagung (Zea mays L.) Pada Berbagai Sistem Pengolahan Tanah dan Variasi Lebar Lorong Tanam. Thesis. Universitas Sumatera Utara Medan.

[8] Gomez, A., and A.A. Gomez. 1984. Prosedur Statistik untuk Penelitian Pertanian. UIPress.

[9] Koestono, 1986. Tehnik Pertanaman Tanpa Olah Tanah dan Pertanaman dengan Pengawetan Tanah. Lokakarya Usahatani Konservasi di Lahan Alang-alang Podzolik Merah Kuning. 11-13 Pebruari 1996. Balitbang Ditjen Tan. Pangan-Ditjenbun Deptan-Monsanto.

[10] Koswara, J. 1982. Jagung. Departemen Agronomi, IPB Bogor. Hal : 1 - 50.

[11] Lal, R. 1986. No-Tillage and Surface-Tillage Systems to Alleviate Soil-Realated Constraints in the Tropics. In : M.A. Sprague and G.B. Triplett (Eds.). NoTillage and Surface Tillage Agriculture. 
The Tillage Revolution. Jhon Wiley \& Sons. $\mathrm{P}$.

[12] Larson, W.E. 1964. Soil Parameter for Evaluating Tillage Needs and Operations. Soil Sci. Amer. Soc. Proc.

[13] Mabbayad, B.B. 1979. Minimum Tillage Shortens Cropping Time. TRE SEARCA. Philippines.

[14] Matsunaka, S. 1983. Evaluation of Rice Weed Control Practices and Research. In : Proceeding of The Conference on Weed Control In Rice. IRRI, Los Banos, Philippines.

[15] McWilliams, D.A., D.R. Berglund, and G.J. Endres. 1999. Corn growth and management quick guide.www.ag.ndsu.edu

[16] Philips, S.H. 1984. No-Tillage Agriculture Principles and Practise. R.E. Philips and S.H. Philps (Eds.). Van Nostrand Reinhold Company Inc.

[17] Radosevich, S.R. and J. S. Holt. 1984. Weed Ecology. Implication for Vegetation Management. A Wiley-Inter Science Publications, New York.

[18] Rahman, A. dan Efris. 1994. Pengaruh Takaran Mulsa Alang-alang Terhadap Pertumbuhan Gulma dan Hasil Jagung, Pros. Konf. HIGI XII, Padang.

[19] Sadjad, S. 1976. Agronomi Umum. Departemen Agronomi. Institut Pertanian. Bogor.

[20] Soepardi, G. 1983a. Sifat dan Ciri Tanah. Departemen Ilmu-ilmu Tanah. IPB Bogor.

[21] Situmeang, R. 2011. Ilmu Tanah. Universitas Simalungun. Pematangsiantar.

[22] Soepardi, G. 1983b. Lahan Untuk Perluasan Pertanian dan Usaha Melestarikan Kesuburan Tanah. Dalam S. Josodiwondo, R. Utji dan W.C. Warsa (Ed.). Mikrobiologi di Indonesia.

[23] Sukman, Y. dan Yakup. 1995. Gulma dan Tehnik Pengendaliannya. PT. Raja Grafindo Persada, Jakarta.

[24] Smith, M.E., C.A. Miles, and J. van Beem. 1995. Genetic improvement of maize for nitrogen use efficiency. In Maize research for stress environment.

[25] Suprapto. 2002. Bertanam Jagung. Penebar Swadaya . Jakarta.

[26] Suryatna, E.S. 1977. Cara Bercocok Tanam Jagung. Bahan Penataran PPs Agronomi. 7
Februari - 12 Maret 1977. Lembaga Pusat Pendidikan Pertanian Bogor.

[27] Sutoro, Yoyo Soelaiman dan Iskandar. 1988. Budidaya Tanaman Jagung. Dalam Subandi, M. Syam, A. Widjono (Ed.). Jagung. BP3. Pusat Penel. Dan Pengb. Tan. Pangan, Bogor.

[28] Utomo, I.H., P. Bangun dan M. Rachman. 1995. Dinamia Populasi Gulma di Lapangan Akibat Pemakaian Herbisida Sejenis. Dalam P. Bangun, Ig.V. Sutarto dan R.C.B. Ginting (Ed.). Pros. Sem. Pengembangan Aplikasi Kombinasi Herbisida, Jakarta, 28 Agustus 1995.

[29] Utomo, W.H. and A.R. Dexter. 1981. Effect of Ageing on the Compression Resistance and Water Stability of Soil Aggregates Disturbed by Tillage, Soil and Tillage Res. 